3. Спиродонов И. П. Кормление сельскохозяйственной птицы: монография / И. П. Спиродонов, А. Б. Мальцев, В. М. Давыдов - Омск: Омск, 2002. - 696 с.

4. Баканов В. А. Кормление сельськохозяйственных животных: монографія / В. А. Баканов, В. К. Мелькин Москва: Агропромиздат, 1989. - 511 с.

5. Свежениов А. И. Корма и кормление сельскохозяйственной птицы: монография / А. И. Свеженцов, Р. М. Рудзик, И. А. Егоров - Днепропетровск: АРТ- ПРЕСС, 2006. - 384 с.

Cite as Vancouver Citation Style

Terzeman D., Karunskyi O. Determination of meat productivity of «Blagovarsky» cross ducks. Grain Products and Mixed Fodder's, 2020; 20 (4, 80): 29-33. DOI https://doi.org/

Cite as State Standard of Ukraine 8302:2015

Determination of meat productivity of «Blagovarsky» cross ducks / Terzeman D. et al. // Grain Products and Mixed Fodder's. 2020. Vol. 20, Issue 4 (80). P. 29-33. DOI https://doi.org/

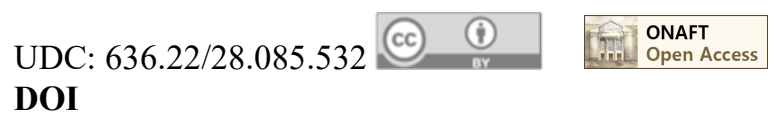

O. Karunskyi, Doctor of Agricultural Sciences, Professor https://orcid.org/ 0000-0001-8180-1587, Researcher ID: B-3788-2016 E.mail: tatianareznik11@gmail.com G.I. Kotets, PhD of Agricultural Sciences M. M. Madani, PhD of Technical Sciences, Associate Professor Odessa State Agrarian University, 13, Panteleimonivska Str., Odessa, 65000, Ukraine

\title{
CHEMICAL COMPOSITION AND NUTRITIONAL VALUE OF THE NEW CITRUS POMACE FEED ADDITIVE
}

The materials of the article present data on research on the chemical, mineral-vitamin composition and nutritional value of a new feed additive from citrus pomace. The article presents the results of research on the technological line of granulation of citrus waste, established the optimal composition for granulation of citrus feed additives: sunflower meal - 20\%, molasses - 5\% and $75 \%$ of citrus fruits.

Their chemical composition was studied, the gross content of proteins, fats, assimilated carbohydrates, including simple sugars, was determined, and the efficiency of use in the diets of farm animals was determined. The positive influence of citrus waste granulation technology has been established, which allows to obtain high-quality granules. Chemical analysis of citrus granules showed that $100 \mathrm{~g}$ contains: protein $-6.15 \mathrm{~g}$, fat $-0.99 \mathrm{~g}$, carbohydrates - $21.8 \mathrm{~g}$, of which simple sugars $14 \mathrm{~g}$, the energy value of this feed additive - Kcal (kJ) - 120.7 (505.7).

The possibility of preparation of feed additives in the form of granules is revealed, which allows to avoid selfsorting of components and overdose of microelements and to improve the consumption of feed ingredients. The ability to prepare feed additives in the form of granules avoids self-sorting of components and overdose of micronutrients and improve the consumption of feed ingredients. The results of zootechnical researches, structure and nutritional value of average daily rations with use of citrus pomace are resulted.

It was found that the introduction into the diet of dairy cows feed additives from citrus pomace during stable lactation increases the average daily expectations by $1.8 \mathrm{~kg}$ or $15.5 \%$, feed costs for milk production containing 4 fat were 0.97-0, 98 feed units. When using a feed additive from citrus pomace, the nutritional value of the diet is improved due to the ratio of sugar - protein (0.62: 1 vs. 0.8: 1.2).

Key words: granules, proteins, fats, carbohydrates, energy value.

\section{Introduction}

Domestic and world experience of increasing the production of livestock products and reducing their cost shows that in recent years an increase in animal productivity by $65 \%$ has been achieved by improving their feeding system and advanced housing technologies. It follows that the organization of rational full-fledged feeding of farm animals is one of the main conditions for further increase of their productivity $[3,5,9]$.
As the knowledge of the animal's need for nutrients increases, so does the concept of the level of a complete diet. Detailed norms and rations of feeding farm animals reflect modern knowledge, on the basis of which a scientifically sound and well-founded feeding system has been developed [1].

Full supply of animals with all nutrients, minerals and biologically active substances, determines not 
only the level of productivity, but also the amount of feed costs for production [8].

With the transfer of animal husbandry to an industrial basis, it is important to develop a system of complete feeding of animals, which ensures their high productivity. It is established that the animal body needs the optimal amount of nutrients and biological substances [1].

Every year, the science of feeding develops tools for the use of various biological and chemical feed additives. High productivity of animals, support of reproductive functions of an organism, effective use of forages is impossible without inclusion in a diet of forage additives which provide necessary level of biologically complete feeding. They are a mandatory ingredient in any diet for farm animals [2.4].

Data on the biological role of individual feed additives, their interaction with other nutrients, dosage taking into account the species and age of animals, methods of administration, the impact on productivity and product quality are necessary for qualified use [7].

The use of supplements also helps to save feed, as a scientifically sound combination of all nutrients and biologically active substances in the diet provides the fullest digestion and assimilation by the body, compared with the components of the diet, which are used separately, fed separately.

The production of feed additives allows to increase the high-energy properties of the diet, to effectively use the ingredients of the diet.

The possibility of preparing feed additives in the form of granules avoids self-sorting of components and overdose of micronutrients and improve the consumption of feed ingredients.

In this regard, it is important to study the chemical composition and nutritional value of citrus pomace and the effectiveness of their use for feed purposes in feeding farm animals.

The main raw materials for the production of new feed additives are citrus pomace.

The use of new feed additives in the diets of farmers. animals is possible only after studying their effectiveness in feeding animals, the impact on health and productivity and their registration in Ukraine.

The purpose of our work was to develop a scheme of the technological line of granulation of citrus waste, to establish their chemical composition. To achieve this goal, the task of our research was:

- determination of the gross content of proteins, fats, assimilated carbohydrates, BAS in particular simple sugars and to identify the effectiveness of use in the diets of farmers animals.

\section{Material and methods of research.}

The experimental part of the work on the development of the technological line of granulation of citrus waste was performed on the basis of LLC "LAMPOCHKA" of the city of Chernomorsk, Odessa region.

Laboratory studies to study the chemical composition of citrus granules were conducted in the Research and Service Company "OTAVA" in 2019.
The fat content in the sample №1157 / 3 was determined according to the method of GOST 32905 2014 (ISO 6492: 1999) "Feed, feed, feed. Method for determination of crude fat content $"$, by extracting crude fat from the product with a solvent, subsequent removal of the solvent, drying and weighing the extracted fat [6.10].

The protein content in sample $1157 / 3$ was determined according to the method of GOST 13496.4-93 "Feed, feed, feed. Methods for determining the content of nitrogen and crude protein "by measuring the nitrogen content and converting the result to the protein content.

The total content of digestible carbohydrates was defined as the sum of simple sugars and carbohydrates that are easily hydrolyzed ("inverted"). Prior to hydrolysis, the content of simple sugars is determined, followed by the determination of the total invert sugar, which consists of the original simple sugars contained in the sample and the simple sugars formed by hydrolysis.

The content of simple sugars in sample 1157/3 was determined according to the method of GOST 590389 "Confectionery". Methods for determination of sugar "by measuring the amount of monovalent copper oxide formed by the iodometric method due to the reaction with reducing substances (simple sugars). Accordingly, the gross content of digestible carbohydrates was determined in a similar manner, after acid hydrolysis of dissolved poly- and oligosaccharides to glucose.

BAS, mineral and vitamin composition of citrus pomace was determined by generally accepted methods [6.10.11].

Methods for determining the above indicators involve working with crushed dry sample. The sample was pre-dried to constant weight at $65^{\circ} \mathrm{C}$ and ground to a powder.

To convert the measurement results to the native state of the sample, the content of volatile substances and water in it was determined. The sample was dried on an automatic moisture meter to a constant weight at a temperature of $65^{\circ} \mathrm{C}$. The moisture and volatile matter content was $2,55 \pm 0,35 \%$ by weight of the sample.

\section{Research results}

Taking into account the useful properties of citrus pomace, a method of processing citrus pomace into feed additives was developed. When citrus was extruded, up to $55-60 \%$ of moisture evaporated from the extrudate, which ensured the moisture content in the feed additive was not more than $12-13 \%$, which allows to store the feed additive for a long time.

The humidity of the mixture before extrusion was not more than $17-19 \%$. The introduction into the mixture of $20 \%$ sunflower meal with a moisture content of $10 \%, 3-7 \%$ molasses with a moisture content of $20 \%$, citrus extrudate $75 \%$ with a moisture content of $15 \%$, made it possible to obtain a mixture with a moisture content of $15 \%$.

Given the results of studies of citrus feed additives, the most effective is the inclusion in the feed additive: sunflower meal - 20\%, molasses $-5 \%$ and $75 \%$ of citrus fruits.

Citrus pomace is prepared separately, for processing, crushed on a grater to a particle size of $2-3 \mathrm{~mm}$, 
homogenized and dosed, after which sunflower meal, molasses are mixed in a mincer. to form a homogeneous mixture.

The granular process is the compression of a homogeneous mass by pressing rollers and the surface of the matrix with round holes. Compression takes place under the action of moisture, heat and pressure, at this time the homogeneous mixture acquires thermo-plastic properties and through the holes of the matrix takes the form of granules.

The temperature of the obtained granules is +60 $80^{\circ} \mathrm{C}$, after that they are sent to the cooler, where they are cooled to a temperature of $18-20^{\circ} \mathrm{C}$. The humidity of the cooled granules did not exceed $6-7 \%$. The floury fraction is obtained after sieving the granules, sent for further granulation. A sample of cylindrical granules with a diameter of 5-6 mm was obtained in Fig. 1.

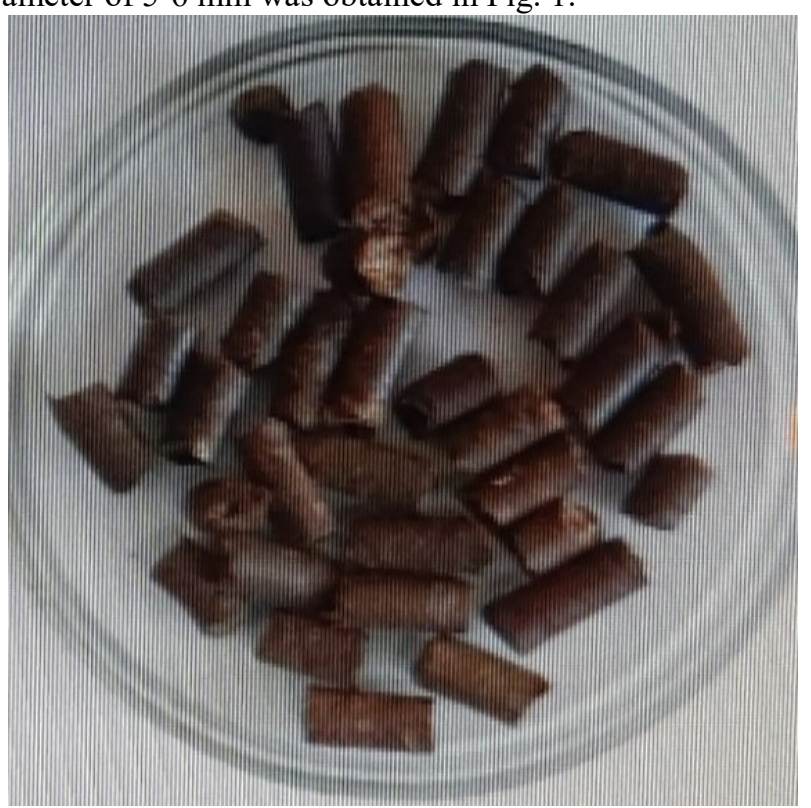

Fig. 1 - Photo of the obtained sample

To use the obtained citrus granules for feed purposes, we conducted a study of chemical composition and nutrition.

The results of determining the content of proteins, fats and carbohydrates are listed on the native state of the sample №1157/3 and the result of calculating the energy value per $100 \mathrm{~g}$ of product are shown in table 1 .

Chemical analysis of citrus granules showed that $100 \mathrm{~g}$ contains: protein- $6.15 \mathrm{~g}$, fat $-0.99 \mathrm{~g}$, carbohydrates - $21.8 \mathrm{~g}$, of which simple sugars $14 \mathrm{~g}$, the energy value of this feed additive is Kcal (kJ) - 120.7 (505.7).

The mineral and vitamin composition of citrus per 100 grams of product are shown in table 2 .

Scientific and economic experiment to study the effectiveness of the use of citrus granules in the diets of dairy cows was carried out for 105 days by the group method according to the scheme shown in table 3 .
Feeding of cows was double, carried out individually, taking into account the specified feed and their residues. The total nutritional value of the rations was determined by detailed norms, the milk yield of cows was carried out individually once every 10 days. The average daily milk yield for the study was taken twice in the transition period and in the main and in the final at the end of each period in proportion to the amount of milk. Eating food during the experiment was quite high. The composition and nutritional value of the average daily rations of experimental animals are shown in table 4.

The data in table 3 indicate that when using a feed additive from citrus pomace, the nutritional value of the diet is improved by the sugar - protein ratio $(0,62: 1$ against $0,8: 1,2)$.

Table 1 - Chemical composition and energy value of the sample №1157 / 3 per $100 \mathrm{~g}$ of product (for the native state of the sample)

\begin{tabular}{||l||c|}
\hline \multicolumn{1}{|c|}{$\begin{array}{c}\text { Indicators, } \\
\text { units of measurement }\end{array}$} & $\begin{array}{c}\text { Value } \\
\text { (per 100 g) }\end{array}$ \\
\hline \hline Protein, g & $6,15 \pm 0,03$ \\
\hline \hline Fat, g & $0,99 \pm 0,05$ \\
\hline \hline $\begin{array}{l}\text { The content of digestible carbo- } \\
\text { hydrates ** (of them simple sug- } \\
\text { ars), g }\end{array}$ & $\begin{array}{c}21,8 \pm 0,04 \\
(14,0 \pm 0,1)\end{array}$ \\
\hline \hline Energy value, kcal $(\mathrm{kJ})$ & $120,7(505,7)$ \\
\hline \hline
\end{tabular}

** - the sum of simple sugars and hydrolyzed (digestible) carbohydrates.

Table 2 - Mineral and vitamin composition of citrus sample №1157/3 per 100 grams of product

\begin{tabular}{||l||l||l||}
\hline \multicolumn{1}{|c||}{ Vitamins } & \multicolumn{1}{|c||}{ Macronutrients } & Trace elements \\
\hline \hline $\mathrm{A}-0,05 \mathrm{mg}$ & $\mathrm{K}-197,0 \mathrm{mg}$ & $\mathrm{Fe}-0,3 \mathrm{mg}$ \\
\hline \hline $\mathrm{B}_{1}-0,04 \mathrm{mg}$ & $\mathrm{Ca}-34,0 \mathrm{mg}$ & $\mathrm{Na}-13,0 \mathrm{mg}$ \\
\hline \hline $\mathrm{B}_{2}-0,03 \mathrm{mg}$ & $\mathrm{Mg}-13,0 \mathrm{mg}$ & $\mathrm{Cl}-3,0 \mathrm{mg}$ \\
\hline \hline $\mathrm{B}_{3}-0,3 \mathrm{mg}$ & $\mathrm{P}-23,0 \mathrm{mg}$ & $\mathrm{B}-180 \mathrm{mcg}$ \\
\hline \hline $\mathrm{B}_{6}-0,006 \mathrm{mg}$ & $\mathrm{S}-9,0 \mathrm{mg}$ & $\mathrm{J}-2,0 \mathrm{mcg}$ \\
\hline \hline $\mathrm{B}_{9}-5,0 \mathrm{mcg}$ & - & $\mathrm{Co}-1,0 \mathrm{mcg}$ \\
\hline $\mathrm{C}-60,0 \mathrm{mg}$ & - & $\mathrm{Mn}-30,0 \mathrm{mcg}$ \\
\hline \hline $\mathrm{E}-0,2 \mathrm{mg}$ & - & $\mathrm{Cu}-67,0 \mathrm{mcg}$ \\
\hline \hline $\mathrm{H}-1,0 \mathrm{mcg}$ & - & $\mathrm{F}-17,0 \mathrm{mcg}$ \\
\hline \hline $\mathrm{PP}-1,0 \mathrm{mcg}$ & - & $\mathrm{Zn}-200,0 \mathrm{mcg}$ \\
\hline \hline
\end{tabular}

Table 3 - The scheme of the experiment

\begin{tabular}{||l||c||c||c||c||}
\hline \multicolumn{1}{|c|}{ Group } & $\begin{array}{c}\text { Number of an- } \\
\text { imal heads }\end{array}$ & $\begin{array}{c}\text { Equalization } \\
\text { period (15 days) }\end{array}$ & \multicolumn{1}{c||}{ Main period (60 days) } & $\begin{array}{c}\text { Final period of } \\
30 \text { days) }\end{array}$ \\
\hline \hline Control & 10 & the basic ration & the basic ration & the basic ration \\
\hline \hline Experimental & 10 & the basic ration & the basic ration $+1,5 \mathrm{~kg}$ citrus pomace & the basic ration \\
\hline
\end{tabular}


Table 4 - The composition and nutritional value of the average daily rations of experimental animals

\begin{tabular}{||l||c|c|}
\hline \multicolumn{1}{|c|}{ FEED } & \multicolumn{2}{c|}{ GROUPS } \\
\cline { 2 - 3 } & Control & Experimental \\
\hline \hline corn silage, $\mathrm{kg}$ & 30 & 30 \\
\hline \hline wheat straw, $\mathrm{kg}$ & 2 & 2 \\
\hline \hline sainfoin hay, kg & 3 & 3 \\
\hline \hline compound feed, $\mathrm{kg}$ & 3 & 2 \\
\hline \hline citrus supplement, $\mathrm{kg}$ & - & 1.5 \\
\hline \hline salt, g & 100 & 100 \\
\hline \hline The ration contains: & \multicolumn{2}{|c|}{} \\
\hline \hline feed units, kg & 16,5 & 16,2 \\
\hline \hline digestible protein, $\mathrm{g}$ & 1250 & 1185 \\
\hline \hline dry substances, kg & 17,2 & 17,8 \\
\hline \hline Ca, g & 152,4 & 148,3 \\
\hline \hline F, g & 78,4 & 81,2 \\
\hline \hline fiber, \% & 16,4 & 16,7 \\
\hline \hline Sugar-protein ratio & $0,62-1$ & $0,8-1,2$ \\
\hline \hline
\end{tabular}

Dairy productivity of cows is shown in table 4 . As can be seen from table 4 , the average daily milk yield was higher in cows of the research group by $1.8 \mathrm{~kg}$ or $15.5 \%$. Therefore, the effectiveness of feeding dairy cows with a feed additive from citrus feed for 105 days of scientific and economic experiment had a positive effect on milk productivity. The cost of feed for milk
Table 5 - Dairy productivity of cows

\begin{tabular}{|c|c|c|}
\hline \multirow[t]{2}{*}{ Indexes } & \multicolumn{2}{|c|}{ Groups } \\
\hline & 1 Control & 2 Experimental \\
\hline Average daily hopes, $\mathrm{kg}$ & 11,6 & 13,4 \\
\hline The fat content in milk, $\%$ & 3,8 & 3,8 \\
\hline $\begin{array}{l}\text { The protein content in } \\
\text { milk, \% }\end{array}$ & 3,64 & 3,61 \\
\hline $\begin{array}{l}\text { Feed costs per } 1 \mathrm{~kg} \text { of } \\
\text { milk } 4 \% \text { fat, feed. units }\end{array}$ & 0,98 & 0,97 \\
\hline
\end{tabular}

production of $4 \%$ fat was almost the same $0.97-0.98$ feed units.

\section{Conclusions}

1. Studies indicate a positive impact of the technological line of granulation of citrus waste, which allows to obtain high quality granules. $100 \mathrm{~g}$ contains: proteins - $6.15 \mathrm{~g}$, fats $-0.99 \mathrm{~g}$, carbohydrates - $21.8 \mathrm{~g}$, of which simple sugars $14 \mathrm{~g}$, the energy value of this feed additive is Kcal (kJ) - 120.7 (505.7).

2. When using a feed additive from citrus pomace, the nutritional value of the diet is improved by sugar - protein ratio (0.62: 1 vs. $0.8: 1.2)$.

3 . Introduction to the diet of dairy cows feed additives from citrus pomace during stable lactation increases the average daily hope by $1.8 \mathrm{~kg}$ or $15.5 \%$, feed costs for milk production of $4 \%$ fat was almost the same 0.97-0.98 feed units.

\section{REFERENCES}

1. Hnoevoy V. Y., Tryshen A. K. Hnoevoy Y. V. Byomorfolohycheskaya orhanyzatsyya y pytatel'nost' kormov. Khar'kov: FLP Borovyn A. V, 2017. 557 s.

2. Humenyuk H. Kormovye dobavky yz vet'sansyr'ya // Kombykormovaya promyshlennost'. - 1997.- №3.- S. 28.

3. Kandyba V. M., Ibatul I. I., Kostenka V. I. Teoriya i praktyka normovanoyi hodivli velykoyi rohatoyi khudoby. Zhytomyr: $P P$ «Ruta», 2012.860s.

4. Yehorov B. V., Shapovalenko O. I., Makaryns'ka A. V. Tekhnolohiya vyrobnytstva premiksiv. Pidruchnyk. - K.:Tsentr uchbovoyi literatury, 2007.-288s.

5. Kotlyar A. Vlyyanye vkusovykh y aromatycheskykh dobavok v ratsyonakh svyney na kachestvo myasa // Svynovodstvo. 1994 - №4 - S. 20-23.

6. Kononenko V. K., Ibatulin I. I., Patrov V. S. Praktykum z osnov naukovykh doslidzhen' u tvarynnytstvi. Kyyiv: 2003.133 s.

7. Svezhentsov F. Y., Korobko V. N. netradytsyonnye kormovye dobavky. - Dnepropetrovsk: Art-Press, 2004.-295 s.

8. Pan'ko V. V. Vykorystannya kompleksnoyi kormovoyi dobavky iz netradytsiynoyi syrovyny $v$ ratsionakh molodnyaka svyney: Dys... kond. s.-h. nauk. - Simferopol', 1995. - 212 s.

9. Chumachenko V. YU., Stoyanovskyy S. V., Lahodyuk P. Z. y dr. Spravochnyk po prymenenyyu byolohychesky aktyvnykh veshchestv $v$ zhyvotnovodstve. - Kyev: Urozhay, 1989. - 261 s.

10. Sheyko V. M., Kushnarenko N. M. orhanizatsiya ta metodyka naukovo-doslidnyts'koyi diyal'nosti: Pidruchnyk. - 4-te vyd., vypr. i dop. - K.: Znannya, 2004. $-307 \mathrm{~s}$.

ІО.Й. Карунський, Д-р с.-г. наук, професор https://orcid.org/ 0000-0001-8180-1587, Researcher ID: B-3788-2016 E.mail: tatianareznik11@gmail.com Г.І. Котець, канд. с.-г. наук,

М. М. Мадані, канд. техн. наук, доцент ${ }^{1}$ Одеський державний аграрний університет, 13, вул. Пантелеймонівська, Одеса, 65000, Украӥна

\section{ХІМІЧНИЙ СКЛАД І ПОЖИВНА ЦІННІСТЬ НОВОЇ КОРМОВОЇ ДОБАВКИ 3 ЦИТРУСОВИХ ВИЧАВОК}

\section{Анотація}

В матеріалах статті представлені дані з проведення досліджень з вивчення хімічного, мінеральновітамінного складу та харчової иінності нової кормової добавки з ичитрусових вичавок. У статті представлені результати досліджень на технологічній лінії грануляції цฺитрусових відходів, встановлено оптимальний склад 
для гранулювання цчитрусової кормової добавки: ирот соняшниковий - 20\%, патока - 5\% та 75\% иุитрусових плодів.

Вивчено їх хімічний склад, визначено валовий вміст білків, жирів, асимільованих вуглеводів, у тому числі простих иукрів та визначена ефективність використання в раціонах сільськогосподарських тварин. Встановлено позитивний вплив технології гранулювання циттрусових відходів, щуо дозволяє отримувати високоякісні гранули. Хімічний аналіз гранул цичтрусових показав, щчо 100 г містить: білка - 6,15 2, жиру - 0,99 2, вуглеводів - 21,8 г, з них простих иукрів 14 г, енергетична цінність иієї кормової добавки - Ккал (кДж) - 120,7 $(505,7)$.

Виявлена можливість приготування кормових добавок у вигляді гранул, щзо дозволяє уникнути самосортування компонентів та передозування мікроелементів та покращити споживання кормових інгредієнтів. Можливість приготування кормових добавок у вигляді гранул дозволяє уникнути самосортування компонентів та передозування мікроелементів та покращити споживання кормових інгредієнтів.Ми вважаємо, що дані про якісні характеристики та харчову иінність кормових добавок із цитрусових вичавок дозволяють припустити, що ию добавку можна використовувати у годівлі великої рогатої худоби. Наведені результати зоотехнічних досліджень, склад і харчова иінність середньодобових раціонів з використанням изитрусових вичавок

Встановлено, щчо введення в рачіон молочних корів кормових добавок з цитрусових вичавок під час стабільної лактації збільшує середньодобові сподівання на 1,8 кг або на 15,5\%, витрати корму на виробництво молока з вмістом 4 жиру були 0,97-0,98 кормових одинииь. При використанні кормової добавки з ичитрусових вичавок харчова иінність раціону покращується за рахунок співвідношення иукор - білок (0,62: 1 проти 0,8: $1,2)$.

Ключові слова: гранули, білки, жири, вуглеводи, енергетична иінність.

\section{ЛІТЕРАТУРА}

1. Гноевой В. И., Тришен А. К. Гноевой И. В. Биоморфологическая организачия и питательность кормов. Харьков: ФЛП Боровин А. В, 2017. 557 c.

2. Гуменюк Г. Кормовые добавки из ветсансырья // Комбикормовая промышленность. - 1997.- №3.- С. 28.

3. Кандиба В. М., Ібатул І. І., Костенка В. І. Теорія і практика нормованої годівлі великої рогатої худоби. Житомир: ПП «Рута», 2012. 860 c.

4. Сгоров Б. В., Шаповаленко О. І., Макаринська А. В. Технологія виробництва преміксів. Підручник. - К.: Центр учбової літератури, 2007. - 288 с.

5. Котляр А. Влияние вкусовых и ароматических добавок в раціонах свиней на качество мяса // Свиноводство. - 1994 - №4 - C. 20-23.

6. Кононенко В. К., Ібатулін І. І., Патров В. С. Практикум з основ наукових досліджень у тваринництві. Київ: 2003. 133 c.

7. Свеженцьов Ф. И., Коробко В. Н. нетрадиционные кормовые добавки. - Днепропетровск: Арт-Пресс, 2004.$295 c$.

8. Панько В. В. Використання комплексної кормової добавки із нетрадиційної сировини в раціонах молодняка свиней: Дис... конд.с.-г. наук. - Сімферополь, 1995. - 212 с.

9. Чумаченко В. Ю., Стояновский С. В., Лагодюк П. З. и др. Справочник по применению биологически активных веществ в животноводстве. - Киев: Урожай, 1989. - 261 с.

10. Шейко В. М., Кушнаренко Н. М. організація та методика науково-дослідниџької діяльності: Підручник. - 4те вид., випр. і доп. - К.: Знання, 2004. -307 c.

Received 28.07.2020
Reviewed 03.09.2020
Revised $\quad 10.11 .2020$

Approved 01.12.2020

Cite as Vancouver Citation Style

Karunskyi O., Kotets G., Madani M. Chemical composition and nutritional value of the new citrus pomace feed additive. Grain Products and Mixed Fodder's, 2020; 20 (4, 80): 33-37. DOI https://doi.org/

Cite as State Standard of Ukraine 8302:2015

Chemical composition and nutritional value of the new citrus pomace feed additive / Karunskyi O. // Grain Products and Mixed Fodder's. 2020. Vol. 20, Issue 4 (80). P. 33-37. DOI https://doi.org/ 